\title{
Kronik Hastalığı Olan Çocukların Annelerinin Bakım Verme Yükü ile Anksiyete-Depresyon Düzeyinin Belirlenmesi
}

\author{
Muradiye Aldem Budak@ $\odot$, Emine Geçkil@
}

Necmettin Erbakan Üniversitesi Hemşirelik Fakültesi, Çocuk Sağlığı ve Hastalıkları Hemşireliği Anabilim Dalı, Konya, Türkiye

Muradiye Aldem Budak, Araş. Gör. Emine Geçkil, Prof. Dr.

Illetişim:

Araş. Gör. Muradiye Aldem Budak Necmettin Erbakan Üniversitesi Hemşirelik Fakültesi, Çocuk Sağlığı ve Hastalıkları Hemşireliği Anabilim Dalı, Konya, Türkiye Tel: +905069174296

E-Posta: ikra42reyhan@gmail.com
ÖZET

Amaç: Kronik hastalığı olan çocukların annelerinde bakım verme yükü ve anksiyete-depresyon risk düzeylerini etkileyen faktörlerin ve ilişkilerinin incelenmesi amaçlandı.

Yöntem: Kronik hastalığı olan çocukların annelerinde kaygı-depresyon ve bakım verme yükünün belirlenmesi amacılla tanımlayıcı olarak planlanmıştır. Araştırmanın evrenini çocuğunun kronik hastalı̆ı nedeniyle Konya'da bir üniversite hastanesinin pediatri ünitesinde yatan anneler oluşturmuştur. Bu çalışma için örnek büyüklüğü $\mathrm{N}=\mathrm{t} 2 * a 2 / \mathrm{d} 2$ formülü ile $(\mathrm{N}=(1,962 * 13,092) / 22)$ hesaplanmış ve 164 kişi bulunmuştur. Veriler sosyodemoğrafik soruları içeren soru formu, Hastanede Anksiyete ve Depresyon (HAD) ölçeği ve Bakım Verme Yükü Ölçeğinin Kasım 2016-0cak2017 tarihleri arasında hastanede yatan annelerden gönüllü olanlara doldurtulması ile toplanmıştır. Veriler sayı, yüzde, ortalama, bağımsız gruplarda t testi, varyans analizi, Tukey HSD testi ile analiz edildi.

Bulgular: Annelerin yaş ortalaması 32,54 $\pm 7,95$, Çocukların yaş ortalaması 5,70 $\pm 5,46$ 'dır. HAD puanları annelerin $\% 57,9^{\prime}$ unun anksiyete riski ve $\% 75,6$ 'sının depresyon riski olduğu belirlendi. Annelerin bakım yükü puanları $26,59 \pm 12,6$ bulundu ve köy/kasabada yaşayanların, çalışmayanların, aylık geliri düşǚk olanların, bakımda yardımıııı olmayanların, çocuğun hastalık süresi uzun olanların, hastaneye sık yatanların bakım yükleri anlamlı şekilde yüksek bulunmuştur $(p<0,05)$. Köy/kasabada yaşayan ve aylık geliri düşük annelerin anksiyete puanları anlamlı şekilde yüksektir. Depresyon puanları incelendiğinde köy/kasabada yaşayan, aylık geliri düşü̈k, çocuk sayısı üç ve üzerinde olan, ç̧cuğunun hastalığı hakkında eğitim alan, ç̧cuğun yaşı büyük olan, uzun süredir tanılanan ve bakım veren, tekrarlı yatışları fazla olan annelerin puanları anlamlı düzeyde yüksek bulunmuştur $(p<0,05)$.

Sonuç: Kronik hastalıklı çocuğu olan annelerin bakım yükü ve anksiyete-depresyon risk düzeyleri artmıştır. Hemşireler kronik hastalıkı çocuğu olan annelere yaklaşımda aile merkezli bakım doğrultusunda bu bulguları dikkate almalıdır.

Anahtar sözcükler: Anne, anksiyete-depresyon, bakım yükü, pediatri hemşireliği, kronik hastalık

\section{THE LEVEL OF ANXIETY-DEPRESSION AND CAREGIVING BURDEN IN MOTHERS OF CHILDREN WITH CHRONIC DISEASES}

\section{ABSTRACT}

Aim: The aim of this study was to investigate the factors affecting the caregiving burden and anxiety-depression risk levels in mothers of children with chronic diseases.

Methods: The population of the descriptive study consists of mothers whose children are inpatients in the pediatric unit of a university hospital in Konya for chronic diseases. The sample size for this study was calculated as $164\left(\mathrm{~N}=\left(1.962^{*} 13.092\right) / 22\right)$. The data were collected by having the voluntary mothers staying in the hospital between November 2016-January 2017 and filling the questionnaire that included sociodemographics, the Hospital Anxiety and Depression Scale (HADS) and Caregiving Burden Scale. Data were analyzed with frequency, percentage, mean, $t$-test in independent groups, variance analysis and Tukey HSD test.

Results: The mean age of the mothers was $32.54 \pm 7.95$ and the mean age of the children was $5.70 \pm 5.46$. The HADS scores were $57.9 \%$ of the mothers with anxiety risk and $75.6 \%$ with depression. The caregiving burden scores of the mothers were found to be $26.59 \pm 12.6$ and it associated with live-in villages/towns, unemployed, low income, no support for caregiving, long duration of the disease and frequency of hospitalization $(p<0.05)$. The anxiety scores of the mothers who live-in villages/towns and who have low monthly income are significantly high. The depression scores of the mothers who live in villages/towns, who have low monthly income, who have 3 or more children, who are trained about the disease of the child, whose children are older with long term diagnosis, who have frequent repetitive inpatient treatment were found to be significantly high $(p<0.05)$.

Conclusion: The burden/responsibility/load of caregiving burden and anxiety-depression risk levels of mothers with chronically ill children increased. Nurses should pay attention to these findings in line with the family-based care in approaching mothers with children with chronic diseases.

Keywords: Mother, anxiety-depression, caregiving burden, pediatric nursing, chronic disease
Gönderilme Tarihi : 05 Ekim 2018

Revizyon Tarihi : 12 Aralık 2018

Kabul Tarihi : 18 Aralık 2018 
K ronik hastalık, normalden sapma veya bozukluk gösteren, kalıc yetersizlik bırakan, patolojik değişiklikler sonucu oluşan, hastanın rehabilitasyonu için özel eğitim gerektiren, uzun süre bakım, gözetim ve denetim gerektiren bir durumdur (1). Kronik hastalıklar çocukluk çağında yaygın olarak görülmekte ve sıklığı giderek artmaktadır. Çocuk hastalıkları polikliniğine başvuran çocukların \%15-50'sinin kanser, diyabet, böbrek hastalıkları, doğumsal anomaliler gibi kronik hastalıklar nedeniyle başvurduğu bildirilmektedir (2).

Hastalığın tanı aşamasından itibaren hastalık süreci nedeniyle çocuk ve aile üyelerinde bazı fizyolojik veya psikolojik sorunlar ortaya çıkabilir $(3,4)$. Kronik hastalığı öğrenen aile sırasıyla şok, akut korku, yadsıma, kızgınlık ve içerleme duygusu, kendisini veya eşini suçlama, durumu kabullenmeme tepkileri göstermektedir (5-10). Daha sonraki süreçlerde hastalığın semptomları ve hastane süreçlerine bağlı olarak bakım verenlerde anksiyete-depresyon sorunları, ölüm korkusu ve hastalık anksiyetesi gelişebilir. Bunun yanında çocuğun sık ve uzun süreli hastaneye yatışına bağlı olarak aile üyelerinin bakım vermedeki yükü artmaktadır $(1,9,11,12)$. Kronik hastalık ve uzun süreli hastaneye yatışlar anne-babanın rollerinin artması/değişmesi, aile sürecinde değişim, ekonomik sorunlar, sosyal yaşamın etkilenmesi, eşler/sağlık ekibi/diğer aile üyeleri arasında iletişim bozukluğu gibi sorunlara neden olabilmektedir $(5,9,12-15)$.

Bakım "bakma işi, bir şeyin iyi gelişmesi, iyi bir durumda kalması için verilen emek, birinin beslenme, giyinme vb. gereksinimlerini üstlenme ve sağlama işi" olarak tanımlanmaktadır (16). Bakım verme yükü, aile içinde diğer sorumlulukları yerine getirirken, yetersizliği olan bir çocuğun günlük bakımını sürdürme ile ilgili olarak yaşanan yoğun anksiyete ve baskı durumudur (1). Bakım vericilerin yükü fiziksel, psikolojik, emosyonel, sosyal ve ekonomik sorunlar olarak çok boyutludur $(2,15,17)$. Kronik hastalığı olan çocuğa bakım verme süresi arttıkça bakım verme yükü de artmaktadır (2).

Kronik hastalık ve hastaneye yatışlar çocuklar başta olmak üzere, aile ve yakınlarında stres, anksiyete, depresyon, kaygı, bakım yükünün artması gibi çeşitli problemlere yol açabilmektedir. Hasta çocukların bakımında genellikle aktif rol alan ve birinci derecede bakımını üstlenen kişiler annelerdir $(18,19)$. Pediatri hemşireleri kronik hastalığı olan çocuğun annelerinin bakım verme yükleri, anksiyete-depresyon düzeylerinin azaltılmasına danışmanlık, eğitim, bakım verme, rehberlik etme rolleri bulunmaktadır.
Bu araştırmada kronik hastalığı olan çocukların annelerinde bakım verme yükü ve anksiyete-depresyon risk düzeylerini etkileyen faktörlerin ve ilişkilerinin incelenmesi amaçlandı.

\section{Yöntem}

\section{Araştırmanın tipi}

Bu araştırma kronik hastalığı olan çocukların annelerinin bakım verme yükü ile anksiyete-depresyonun risk düzeyleri ve bunları etkileyen faktörlerin belirlenmesi amacıyla tanımlayıcı olarak yapılmıştır.

\section{Araştırmanın yapıldığı yer}

Konya Necmettin Erbakan üniversitesi hastanesi çocuk kliniklerinde gerçekleştirildi. Necmettin Erbakan üniversitesi hastanesinde çocuk cerrahi servisi 12 , intaniye servisi 11 , genel servis (1) 15, genel servis (2) 11, çocuk yoğun bakım 9, çocuk hematoloji 18, çocuk kardiyoloji 15 , çocuk endokrin ve nöroloji 14 yatak kapasitesi olmak üzere toplam 105 yatak kapasitesine sahiptir.

\section{Araştırmanın evreni ve örneklem}

Araştırmanın evrenini Kasım 2016-Ocak 2017 tarihleri arasında kronik hastalık nedeniyle hastaneye yatışı yapılan çocukların anneleri oluşturmuştur.

Örnek büyüklüğünü hesaplamada $n=\left(t^{2} \cdot a^{2}\right) / d^{2}$ formülünden yararlanılmıştır (20).

Formülde;

$\mathrm{n}=$ örnekleme alınacak birey sayısı.

$a=e v r e n$ standart sapması. (Alahan ve ark 2015 saptanan 13,09)

$\mathrm{t}=$ belirli serbestlik derecesinde ve saptanan yanılma düzeyinde $t$ tablosundan bulunan teorik değer. (\%95 güven aralığında 1,96 olarak kabul edilmiştir)

$\mathrm{d}=$ ortalamaya göre yapılmak istenen \pm sapma $( \pm 2$ olarak kabul edilmiştir) (20).

Araştırmanın örnek büyüklüğünün belirlenmesinde, Alahan ve arkadaşlarının 2015 yılında yaptığı kronik hastalığı olan çocuğa sahip ebeveynlerin bakım verme yükü puan ortalamasından yararlanılmıştır. Bu çalışma için örnek büyüklüğü $\% 95$ güven seviyesi \pm 2 puan olan güven aralığı içinde, standart sapması 13,09 (2) kabul edilerek hesaplanmıştır. $\mathrm{N}=\left(1,96^{2} \times 13,09^{2}\right) / 2^{2}$ sonucunda 164 olarak belirlenmiştir. Veriler kurumdan izin alındıktan sonra Kasım 2016-Ocak2017 tarihleri arasında toplanmıştır. 
Veri toplama araçları ve verilerin toplanması

Verilerin toplanmasında sosyo-demografik bilgi formu, Hastanede Anksiyete ve Depresyon Ölçeği, Bakım Verme Yükü Ölçeği kullanılmıştır.

Sosyo-demografik bilgi formu annelerin yaş, medeni durum, öğrenim durumu, bakım verilen süre vb. bilgilerin yanında çocuğa yönelik yaş, cinsiyet, tıbbi tanı, hastalık süresi vb. bilgileri içeren maddelerden oluşmaktadır.

Bakım Verme Yükü Ölçeği (BVYÖ), Zarit, Reever ve BachPeterson tarafından 1980 yılında geliştirilmiştir. Ölçeğin Türkçe geçerlilik ve güvenirliliği İnci ve Erdem (2008) tarafından yapılmıştır. Bakım gereksinimi olan bireye veya yaşlıya bakım verenlerin yaşadığı stresi değerlendirmek amacıyla kullanılan bir ölçektir. Bakım verenlerin kendisi ya da araştırmacı tarafından sorularak doldurulabilen ölçek, bakım vermenin bireyin yaşamı üzerine olan etkisini belirleyen 22 ifadeden oluşmaktadır. Ölçek 0 ile 4 arası puanlamaya sahip beşli likert tipi değerlendirmeye sahiptir. Ölçekten en az 0, en fazla 88 puan alınabilmektedir. Ölçek puanının yüksek olması yaşanılan sıkıntının yüksek olduğunu göstermektedir (21).

Hastanede Anksiyete ve Depresyon (HAD) Ölçeği Zigmond ve Snaith tarafından 1983 yılında geliştirilmiştir. Ölçeğin Türkçeye uyarlanmasını Aydemir ve ark. (1997) tarafından yapılmıştır. Ölçek 14 maddeden oluşmaktadır ve yedi madde (tek sayılar) anksiyeteyi, diğer yedisi (çift sayılar) depresyonu taramaktadır. Dörtlü likert tipi bir ölçektir. Yapılan geçerlilik ve güvenilirlik çalışması sonucunda anksiyete alt boyutu (HAD-A) için kesme puanı 10, depresyon alt boyutu (HAD-D) için kesme puanı 7 olarak bildirilmiştir (22).

Kronik hastalık nedeniyle yatış yapılan çocukların annelerine araştırmanın amacı açıklanarak araştırmaya katılmayı kabul eden annelere veri toplama formu verildi. Veriler hasta odası uygun ise hasta odasında, hasta odasının uygun olmadığı durumlarda hemşire odasında annelerin anket formu cevaplandıktan sonra geri alınması ile toplandı. Anket formunun cevaplanması ortalama 10 dk sürdü.

\section{Araştırmaya alınma kriterleri}

Araştırma çocuk kliniklerinde kronik hastalık ile yatışı yapılan hastaların anneleri ile yürütülmüştür. Araştırmaya katılmayı kabul eden, Türkçe okuryazarlığı olan ve okuduğunu anlayan anneler dâhil edilmiştir.

\section{Ön uygulama}

Veri toplama formunun anlaşılırlığını test etmek için anket formu, araştırmanın öncesinde çocuk servislerinden birinde kronik hastalık nedeniyle yatışı yapılan beş çocuk annesine uygulandı ve anlaşılmayan soru olmadığı görüldü.

\section{Verilerin değerlendirilmesi}

Verilerin istatistiksel analizi için SSPS 20,0 paket programından yararlanıldı. Tanımlayıc istatistiksel testler sayı, yüzde, ortalama, standart sapma kullanıldı. KolmogorovSmirnov testi, skewness ve kurtosis değerleri sonucunda veriler normal dağılım gösterdiğinden bağımsız iki gruba ait ölçek ortalamaları karşılaştırılırken bağımsız gruplarda t-testi, bağımsız ikiden fazla gruba ait ölçek ortalamaları karşılaştırılırken tek yönlü varyans analizi, post hoc test olarak Tukey HSD testi kullanıldı. Verilerin arasındaki ilişkinin incelenmesinde; verilerin doğrusal, sürekli, normal dağılım gösterdiği için korelasyon katsayıları önemlilik testi analizi kullanıldı.

\section{Araştırmanın etik boyutu}

Araştırmanın etik kurul izni Necmettin Erbakan Üniversitesi Meram Tıp Fakültesi İlaç ve Tıbbi Cihaz Dışı Araştırmalar Etik Kurulu'ndan 2016/541 sayılı karar ile onay verilmiştir. Kurum izni için Meram Tıp Fakültesi Hastane Yöneticisinden yazılı onay alındı. Ayrıca veri toplamadan önce katılımcılara araştırmanın amacı açıklanarak, araştırmaya katılmayı kabul ettiklerine yönelik sözel onamları alındı.

\section{Araştırmanın sınırlılıkları}

Araştırmanın Konya kent merkezinde bir hastanede yatışı yapılan hastaların annelerine uygulanmıştır, sonuçlar bu gruba genellenebilir.

\section{Bulgular}

Bu araştırmaya katılan 164 annenin yaş ortalaması 32,54 $\pm 7,95$, \%48,2'si 29-38 yaş grubunda, \%93,9'u evli ve \%46,3'ü ilkokul öğrenim düzeyindedir. Annelerin \%91,5'inin herhangi bir meslekte çalışmadığı, \%14,6'sının aylık gelir düzeyi düşük olduğu, \%40,9'unun iki ve üzerinde çocuğa sahip olduğu, \%53'ünün çocuğun bakımına yardımcı kişi veya kişiler bulunduğu, \%59,1'inin çocuğuna bakım vermesi sırasında diğer çocuklarının bakımı ve rollerinin etkilendiği, \%55,5'inin çocuğunun hastalığı hakkında eğitim aldığı saptandı (Tablo 1).

Annelerin bakım verme yükü ölçeği puan ortalaması ile sosyo-demografik verileri arasındaki ilişki incelendiğinde; köy/kasabada yaşayan annelerin bakım verme yükü puan ortalamasının ilçede yaşayanlara göre anlamlı derecede yüksek olduğu $(p<0,05)$ bulundu. Herhangi bir 
Tablo 1. Annelerin sosyo-demografik özellikleri ile HADÖ ve BVYÖ puan ortalamalarının karşılaştıııması

\begin{tabular}{|c|c|c|c|c|}
\hline Özellikler & $N(\%)$ & BVYÖ & $H A D-A$ & $H A D-D$ \\
\hline \multicolumn{5}{|c|}{ Anne yaşı (ort $32,54 \pm 7,95$ ) } \\
\hline $18-28$ yaş & $53(32,3)$ & $25,05 \pm 12,57$ & $11,33 \pm 4,32$ & $9,52 \pm 4,24$ \\
\hline 29-38 yaş & $79(48,2)$ & $27,39 \pm 12,72$ & $11,64 \pm 3,96$ & $10,03 \pm 3,78$ \\
\hline 39 yaş ve $\uparrow$ & $32(19,5)$ & $27,18 \pm 12,71$ & $11,46 \pm 4,05$ & $10,50 \pm 4,31$ \\
\hline $\mathrm{F} / \mathrm{p}$ & & $0,582 / 0,560$ & $0,090 / 0,914$ & $0,603 / 0,549$ \\
\hline \multicolumn{5}{|l|}{ Medeni durum } \\
\hline & $154(93,9)$ & $26,92 \pm 12,55$ & $11,52 \pm 4,11$ & $9,93 \pm 4,01$ \\
\hline Bekar/diğer & $10(6,1)$ & $21,60 \pm 13,58$ & $11,30 \pm 3,62$ & $10,40 \pm 4,50$ \\
\hline$t / p$ & & $1,293 / 0,198$ & $0,169 / 0,866$ & $0,352 / 0,725$ \\
\hline \multicolumn{5}{|l|}{ Öğrenim düzeyi } \\
\hline İlkokul & $76(46,3)$ & $28,40 \pm 12,15$ & $11,86 \pm 4,03$ & $10,31 \pm 3,81$ \\
\hline Ortaokul & $44(26,8)$ & $25,65 \pm 12,21$ & $11,27 \pm 4,36$ & $10,25 \pm 3,93$ \\
\hline Lise ve üstü & $44(26,8)$ & $24,40 \pm 13,69$ & $11,13 \pm 3,89$ & $9,06 \pm 4,42$ \\
\hline $\mathrm{F} / \mathrm{p}$ & & $1,571 / 0,211$ & $0,549 / 0,579$ & $1,495 / 0,227$ \\
\hline \multicolumn{5}{|l|}{ Aile yapısı } \\
\hline Çekirdek aile & $119(72,6)$ & $26,73 \pm 12,34$ & $11,31 \pm 4,11$ & $9,63 \pm 4,08$ \\
\hline Geniş aile & $37(22,6)$ & $27,27 \pm 13,66$ & $12,43 \pm 3,86$ & $11,18 \pm 3,54$ \\
\hline Ayrılmış aile & $8(4,9)$ & $21,50 \pm 12,54$ & $10,12 \pm 4,18$ & $9,12 \pm 4,67$ \\
\hline $\mathrm{F} / \mathrm{p}$ & & $0,707 / 0,495$ & $1,547 / 0,216$ & $2,305 / 0,103$ \\
\hline \multicolumn{5}{|l|}{ Yaşanılan yer } \\
\hline Şehir & $101(61,6)$ & $26,48 \pm 12,81$ & $11,53 \pm 3,92$ & $10,13 \pm 3,68$ \\
\hline İlçe $\mathrm{e}^{\mathrm{a}}$ & $33(20,1)$ & $22,96 \pm 10,27$ & $9,81 \pm 4,23$ & $8,21 \pm 4,34$ \\
\hline Köy/kasabab & $30(18,3)$ & $30,96 \pm 13,42$ & $13,30 \pm 3,76$ & $11,30 \pm 4,28$ \\
\hline $\mathrm{F} / \mathrm{p}$ & & $3,242 / 0,042(b>a)$ & $6,084 / 0,003(b>a)$ & $5,101 / 0,007(b>a)$ \\
\hline \multicolumn{5}{|c|}{ Anne meslek sahibi olma durumu } \\
\hline Çalışıyor ${ }^{\mathrm{a}}$ & $14(8,5)$ & $19,92 \pm 15,16$ & $11,42 \pm 3,52$ & $9,92 \pm 2,23$ \\
\hline Çalışmıyor ${ }^{b}$ & $150(91,5)$ & $27,22 \pm 12,25$ & $11,52 \pm 4,13$ & $9,96 \pm 4,16$ \\
\hline$t / p$ & & $2,085 / 0,039(b>a)$ & $0,080 / 0,936$ & $0,034 / 0,973$ \\
\hline \multicolumn{5}{|c|}{ Ailenin aylık geliri } \\
\hline Kötü a & $24(14,6)$ & $33,08 \pm 11,93$ & $13,41 \pm 3,88$ & $11,83 \pm 3,13$ \\
\hline Orta $^{b}$ & $123(75)$ & $26,44 \pm 12,353$ & $11,26 \pm 4,14$ & $9,60 \pm 4,22$ \\
\hline İyic & $17(10,4)$ & $18,52 \pm 11,26$ & $10,64 \pm 3,21$ & $9,88 \pm 3,07$ \\
\hline $\mathrm{F} / \mathrm{p}$ & & $7,130 / 0,001(a>b>c)$ & $3,324 / 0,038(a>b)$ & $3,138 / 0,046(a>b)$ \\
\hline \multicolumn{5}{|l|}{ Çocuk sayısı } \\
\hline 1 çocuk $^{\mathrm{a}}$ & $30(18,3)$ & $21,76 \pm 13,70$ & $10,86 \pm 4,16$ & $8,0 \pm 3,45$ \\
\hline 2 çocuk $^{b}$ & $67(40,9)$ & $28,22 \pm 12,45$ & $12,35 \pm 4,01$ & $10,05 \pm 3,96$ \\
\hline 3 ve $\uparrow$ çocuk $^{c}$ & $67(40,9)$ & $27,13 \pm 11,97$ & $10,95 \pm 4,01$ & $10,74 \pm 4,09$ \\
\hline $\mathrm{F} / \mathrm{p}$ & & $2,870 / 0,060$ & $2,485 / 0,087$ & $5,081 / 0,007(c>b>a)$ \\
\hline \multicolumn{5}{|c|}{ Çocuğun bakımına yardımcı kişi veya kişilerin varlığı } \\
\hline Yardımcı vara & $87(53)$ & $24,01 \pm 12,87$ & $11,39 \pm 4,16$ & $9,70 \pm 3,62$ \\
\hline Yardımcı yok & $77(47)$ & $29,51 \pm 11,78$ & $11,64 \pm 4,00$ & $10,25 \pm 4,45$ \\
\hline$t / p$ & & $2,845 / 0,005(b>a)$ & $0,404 / 0,687$ & $0,885 / 0,378$ \\
\hline \multicolumn{5}{|c|}{ Bakım süresinde rolün etkilenmesi } \\
\hline Etkilendia $^{a}$ & $97(59,1)$ & $28,39 \pm 13,69$ & $12,19 \pm 4,14$ & $10,72 \pm 4,10$ \\
\hline Etkilenmedib & $67(40,9)$ & $24,00 \pm 10,49$ & $10,52 \pm 3,80$ & $8,86 \pm 3,67$ \\
\hline$t / p$ & & $2,322 / 0,022(a>b)$ & $2,629 / 0,009(a>b)$ & $2,966 / 0,003(a>b)$ \\
\hline \multicolumn{5}{|c|}{ Çocuğun hastalığı hakkında eğitim alma } \\
\hline Eğitim almış ${ }^{\mathrm{a}}$ & $91(55,5)$ & $28,86 \pm 12,94$ & $11,90 \pm 4,01$ & $10,58 \pm 3,96$ \\
\hline Eğitim almamış & $73(44,5)$ & $23,76 \pm 11,73$ & $11,02 \pm 4,13$ & $9,19 \pm 4,00$ \\
\hline$t / p$ & & $2,614 / 0,010(a>b)$ & $1,367 / 0,174(a>b)$ & $2,221 / 0,028(a>b)$ \\
\hline
\end{tabular}


meslekte çalışmayan annelerin bakım verme yükü puan ortalamaları çalışan anneler kıyasla daha yüksek olduğu $(p<0,05)$, ailenin aylık gelir düzeyi düştükçe annelerin bakım verme yükü puan ortalamalarının arttığı $(p<0,01)$ saptandı. Aile içerisinde çocuğun bakımına yardımcı kişi veya kişilerin olmamasının annelerin bakım verme yükü puan ortalamaları anlamlı yükselttiği $(p<0,01)$, çocuğunun hastalığı hakkında eğitim almakla bakım verme yükü ölçeği puan ortalamaların anlamlı yüksek olduğu $(p<0,05)$ belirlendi (Tablo 1).

Annelerin anksiyete-depresyon puan ortalaması ile sosyo-demografik veriler arasındaki ilişki incelendiğinde; köy/kasabada yaşayan annelerin ilçede yaşayan annelere göre anksiyete-depresyon puan ortalamalarının anlamlı derecede yüksek olduğu $(p<0,01)$ belirlendi. Aylık gelir miktarı kötü olan ailelerin aylık gelir miktarı orta olanlara oranla anksiyete-depresyon puan ortalamalarının anlamlı yükseldiği $(p<0,05)$ bulundu. Annelerin çocuklarına bakım vermesi sırasında diğer rollerinin etkilenmesiyle anksiyete-depresyon puan ortalamalarının arttığı $(p<0,01)$, çocuğunun hastalığı hakkında eğitim alan annelerin anksiyetedepresyon puan ortalaması eğitim almayan annelerden anlamlı yüksek olduğu $(p<0,05)$ tespit edildi (Tablo 1$)$.

Araştırmaya katılan annelerin çocuklarının yaş ortalaması 5,70 $\pm 5,46$, çocukların yarısından fazlası kız, çoğunluğu 7 yaş ve üzerindedir. Çocukların üçte biri solunum sistemi rahatsızlığı yaşadığı, \%57,9'unun 0,1-1 yıldır bakım aldığı, \%49,4'ünün 1-5 kez hastaneye yattığı, çocukların $\% 57,3$ 'ünün 0,1-1 yıldır hastalık tanısı aldığı belirlendi (Tablo 2).

Tablo 2. Çocukların sosyo-demografik özellikleri ile HADÖ ve BVYÖ puan ortalamalarının karşılaştırımas

\begin{tabular}{|c|c|c|c|c|}
\hline Özellikler & $N(\%)$ & BVYÖ & $H A D-A$ & $H A D-D$ \\
\hline \multicolumn{5}{|c|}{ Çocuğun yaşı (ort $5,70 \pm 5,46$ ) } \\
\hline $0-1$ yaşa $^{a}$ & $48(29,3)$ & $23,18 \pm 10,84$ & $11,02 \pm 4,19$ & $8,70 \pm 3,89$ \\
\hline $1-3$ yaş $^{b}$ & $35(21,3)$ & $31,14 \pm 12,52$ & $11,71 \pm 4,06$ & $9,91 \pm 4,66$ \\
\hline 3-6 yaş & $25(15,2)$ & $24,84 \pm 12,09$ & $10,12 \pm 3,84$ & $10,32 \pm 3,81$ \\
\hline 7 yaş ve $\uparrow c$ & $56(34,1)$ & $27,46 \pm 13,66$ & $12,42 \pm 3,95$ & $10,91 \pm 3,61$ \\
\hline$\underline{F / p}$ & & $3,031 / 0,031(b>a)$ & $2,222 / 0,088$ & $2,732 / 0,046(c>a)$ \\
\hline \multicolumn{5}{|l|}{ Çocuğun cinsiyeti } \\
\hline $\mathrm{KIz}$ & $91(55,5)$ & $26,30 \pm 12,94$ & $11,80 \pm 3,98$ & $9,83 \pm 3,98$ \\
\hline Erkek & $73(44,5)$ & $26,95 \pm 12,33$ & $11,15 \pm 4,19$ & $10,12 \pm 4,10$ \\
\hline$t / p$ & & $0,327 / 0,744$ & $1,016 / 0,311$ & $0,454 / 0,651$ \\
\hline \multicolumn{5}{|c|}{ Çocuğun hastalık sınıflaması } \\
\hline Solunum sistemi & $53(32,3)$ & $26,05 \pm 12,09$ & $11,35 \pm 4,60$ & $8,77 \pm 4,50$ \\
\hline Hematolojik sistem & $39(23,8)$ & $25,94 \pm 11,76$ & $11,76 \pm 3,81$ & $10,87 \pm 2,68$ \\
\hline MSS & $31(18,9)$ & $26,83 \pm 12,77$ & $10,87 \pm 3,90$ & $9,41 \pm 4,27$ \\
\hline İmmün sistem & $10(6,1)$ & $30,60 \pm 17,28$ & $13,10 \pm 3,21$ & $12,00 \pm 2,53$ \\
\hline Diğer sistemler & $31(18,9)$ & $26,80 \pm 13,41$ & $11,58 \pm 3,93$ & $10,74 \pm 4,23$ \\
\hline $\mathrm{F} / \mathrm{p}$ & & $0,300 / 0,877$ & $0,624 / 0,646$ & $0,839 / 0,069$ \\
\hline \multicolumn{5}{|l|}{ Bakım verilen süre } \\
\hline $0,1-1 \mathrm{yll}^{\mathrm{a}}$ & $95(57,9)$ & $23,91 \pm 11,43$ & $11,26 \pm 3,84$ & $9,63 \pm 3,85$ \\
\hline $1-7 y \|^{b}$ & $52(31,7)$ & $28,30 \pm 13,70$ & $12,07 \pm 4,35$ & $10,44 \pm 4,44$ \\
\hline $7 \mathrm{yll}$ ve $\uparrow \mathrm{c}$ & $17(10,4)$ & $36,35 \pm 10,40$ & $11,17 \pm 4,58$ & $10,35 \pm 3,67$ \\
\hline $\mathrm{F} / \mathrm{p}$ & & $8,371 / 0,000(c>b>a)$ & $0,730 / 0,483$ & $0,766 / 0,467$ \\
\hline \multicolumn{5}{|c|}{ Kaç kere hastaneye yatış oldu } \\
\hline $1-5 \mathrm{kez}^{\mathrm{a}}$ & $81(49,4)$ & $22,67 \pm 11,81$ & $10,98 \pm 4,02$ & $9,13 \pm 3,78$ \\
\hline 6-11 kez & $27(16,5)$ & $27,11 \pm 13,36$ & $11,48 \pm 3,23$ & $11,51 \pm 4,07$ \\
\hline 12 ve $\uparrow \mathrm{c}$ & $56(34,1)$ & $32,01 \pm 11,55$ & $12,28 \pm 4,45$ & $10,41 \pm 4,12$ \\
\hline $\mathrm{F}$ & & $10,072 / 0,000(c>a)$ & $1,691 / 0,188$ & $4,220 / 0,016(b>a)$ \\
\hline \multicolumn{5}{|l|}{ Çocuğun tanı süresi } \\
\hline $0,1-1 \mathrm{yll}^{\mathrm{a}}$ & $94(57,3)$ & $23,96 \pm 11,48$ & $11,21 \pm 3,82$ & $9,52 \pm 3,72$ \\
\hline $1-7 \mathrm{yll}^{\mathrm{b}}$ & $51(31,1)$ & $27,68 \pm 13,64$ & $11,92 \pm 4,26$ & $10,62 \pm 4,66$ \\
\hline $7 \mathrm{yll}$ ve $\uparrow \mathrm{c}$ & $19(11,6)$ & $36,68 \pm 10,09$ & $11,89 \pm 4,84$ & $10,36 \pm 3,56$ \\
\hline$F / p$ & & $9,094 / 0,000(c>b>a)$ & $0,590 / 0,555$ & $1,359 / 0,260$ \\
\hline
\end{tabular}

$a, b, c$ : 
Bakım verenlerin yükü puan ortalaması ile çocukların sosyo-demografik verileri arasındaki ilişki incelendiğinde; annelerin bakım yükü puan ortalaması 1-3 yaş grubu çocuğa sahip annelerin $0-1$ yaş çocuğa sahip annelerden anlamlı yüksek olduğu saptandı $(p<0,05)$. Annelerin bakım verme yükü puan ortalamasının çocuğa bakım verilen sürenin ve çocuğun tanı süresinin uzamasıyla arttığı belirlendi $(p<0,01)$, hastaneye 12 ve üzerinde yatışııın olmasıyla 1-5 kez hastaneye yatışı olan çocukların annelerinin puanları arasındaki fark anlamlı $(p<0,05)$ bulundu (Tablo 2).

Çocuklarının yaşı yedi ve üzerinde olan annelerin depresyon puan ortalamaları 0-1 yaş grubunda olan annelere göre anlamlı yüksek olduğu saptandı $(p<0,05)$. Çocukları hastaneye 6-11 kez yatan annelerin depresyon puanının 1-5 kez yatan çocukların annelerin puanından anlamlı şekilde yüksek olduğu $(p<0,05)$ tespit edildi (Tablo 2$)$.

Annelerin bakım yükü ölçeği puan ortalaması $26,59 \pm 12,6$ olarak hesaplandı. Annelerin hastanede anksiyete-depresyon ölçeği anksiyete riski alt boyutu puan ortalaması $11,51 \pm 4,07$ olarak belirlendi. Annelerin \%57,9'unda anksiyete riski bulunmaktadır. Depresyon riski alt boyutunda annelerin puan ortalaması $9,96 \pm 4,03$ bulundu ve annelerin \%75,6'sının depresyon riski altında olduğu saptandı (Tablo 3).

\begin{tabular}{|c|c|c|c|c|}
\hline Özellikler & Ortalama $\pm S S$ & & Sayı & $\%$ \\
\hline \multirow[t]{2}{*}{ Anksiyete } & $11,51 \pm 4,07$ & $\begin{array}{c}\text { Risk var } \\
\text { Anksiyete puanı }>10\end{array}$ & 95 & 57,9 \\
\hline & & $\begin{array}{c}\text { Risk yok } \\
\text { Anksiyete puanı }<10\end{array}$ & 69 & 42,1 \\
\hline \multirow[t]{2}{*}{ Depresyon } & $9,96 \pm 4,03$ & $\begin{array}{c}\text { Risk var } \\
\text { Depresyon puanı }>7\end{array}$ & 124 & 75,6 \\
\hline & & $\begin{array}{c}\text { Risk yok } \\
\text { Depresyon puanı }<7\end{array}$ & 40 & 24,4 \\
\hline BVYÖ & $26,59 \pm 12,6$ & & & \\
\hline
\end{tabular}

Bakım verme yükü ile hastanede anksiyete-depresyon ölçeği arasındaki ilişki incelendiğinde; bakım verme yükü ile anksiyete alt boyutu arasında $(r=0,424 ; p<0,01)$ ve depresyon alt boyutu $(r=0,243 ; p<0,01)$ arasında pozitif yönde ve anlamlı ilişki olduğu belirlendi. Bakım verme yükü arttıkça annelerin anksiyete, depresyon puanları artmaktadır. Annelerin anksiyete ve depresyon alt boyutları arasındaki ilişki incelendiğinde; anksiyete ve depresyon puan ortalamaları arasında $(r=0,473 ; p<0,01)$ pozitif yönde ve anlamlı derecede ilişki olduğu tespit edildi (Tablo 4).
Tablo 4. HADÖ ve BVYÖ puan ortalamaları korelasyonu

\begin{tabular}{lccc} 
& BVYÖ & HAD-A & HAD-D \\
\hline BVYÖ & 1 & $0,424(p 0,000)$ & $0,243(p 0,002)$ \\
HAD-A & $0,424(p 0,000)$ & 1 & $0,473(p 0,000)$ \\
HAD-D & $0,243(p 0,002)$ & $0,473(p 0,000)$ & 1
\end{tabular}

\section{Tartışma}

Araştırmada, çocuğu kronik hastalığa sahip olan 164 annede bakım verme yükü ve anksiyete-depresyon risk düzeyleri değerlendirildi. Annelerin bakım verme yükü puan ortalaması $26,59 \pm 12,6$ bulundu. Literatür incelendiğinde kronik hastalığı sahip çocukların anneleriyle yapılan çalışmalarda bakım yükü puan ortalamaları 30 ile 52 arasında değiştiği tespit edilmiştir (2, 23-25). Bu araştırmada annelerin bakım verme yükü puan ortalaması literatüre göre daha düşük bulundu. Bu sonuç çalışma grubundaki annelerin çoğunluğunun bakım verme süresinin daha kısa (0,1-1 yıl) olmasından kaynaklı olduğu düşünüldü.

Araştırmada köy/kasabada yaşayan annelerin bakım verme yükü puan ortalamaları ilçede yaşayan annelere göre daha yüksek tespit edildi. Literatürde yaşanılan yerin kırsal bölge olması aile içinde bakım yükünü artırdığı belirtilmektedir (14). Kırsal bölge ile hastane arası ulaşımın zorlaşması, yaşanılan yerde yeterli sağlık hizmeti alacak imkânların olmaması annelerin bakım yükünü artırabilir.

Anneler arasında herhangi bir meslekte çalışmama ve aylık gelirin düşmesi annelerin, bakım verme yükü puan ortalamasını artırmaktadır. Benzer çalışmalarda da ekonomik durumun kötü olmasının bakım yükünü artırdığı belirlenmiştir $(2,4,15,17,26)$. Kronik hastalık sürecinde ailenin tedavi masrafları, eğitim, bakıma yönelik araç gereç temini gibi nedenlerle ekonomik giderleri artmaktadır (1, 19). Bakım sürecinin aileye ekonomik yük getirmesi annelerin bakım verme yükünü artırmaktadır.

Annelerin bakım verme yükü puan ortalamasını çocuğun bakımına yardımcı kişi/kişilerin olmaması ve bakım verme sırasında annelerin rollerinde değişiklik olmasının artırdığı belirlendi. Yapılan diğer çalışmalarda da bakıma yardımcı bireylerin olmamasının bakım yükünü artırdığı belirlenmiştir $(15,27)$. Benzer şekilde, Alahan ve ark.'nın (2015) kronik hastalığı olan çocuğa sahip ebeveynlerle yaptıkları çalışmada aile ve iş ortamında rolü etkilenen kişilerin bakım yükü puanlarının yüksek olduğunu bildirmişlerdir (2). Başka bir çalışmada da bakım sırasında başka sorumluluklarının olması kişilerin bakım yükü puan ortalamasını arttığı belirtilmiştir (15). Bakım veren 
kişilerin aile, arkadaş, özel bir kişi ya da bir başka kişiden sosyal destek alması bakım yükü puan ortalamasını düşürmektedir (28). Toplum içerisinde annenin birçok sorumluluğu bulunmaktadır. Ev işleri ve çocuk bakımı genellikle annelerin sorumlulukları arasındadır. Aile içerisinde çocuğun hasta olması anneden beklenen sorumlulukların aksamasına bunun sonucunda da annelerin pek çok sorumlulukla birlikte kronik hastalığı olan çocuğun özel bakım işini üstlenmesi bakım yükü puan ortalamalarını artmasına neden olmaktadır. Annelerin bakım verme sürecinde desteklerinin olması onların hem sosyal hayatlarında daha aktif hem de bakımı sürdürmede daha başarılı olacaklarını ayrıca aile içerisinde rollerini devam ettirmede yeterli olacaklarını göstermektedir. Hemşireler çocuğunun kronik hastalığı olan annelerin sosyal desteklerini ve annelerin rollerini değerlendirmelidir. Bakımda yardım gereksinimlerinin karşılanması ve rollerinin kolaylaştırılması için yardımcı olmaktadır.

Çocuğunun hastalığı hakkında eğitim alan annelerin bakım verme yükü puan ortalamalarının daha yüksek olduğu bulundu. Alahan ve ark.'nın (2015) bakım hakkında bilgi sahibi olmayan annelerin daha yüksek bakım yükü puan ortalamasına sahip olduğunu belirtmişlerdir. Bu sonucun annelerin hastalık, hastalık süreci ve çocuklarının geleceği hakkında bilgilerin içeriği ile ilişkili olabileceği ve bu konunun incelenmesi gerektiği düşünülmüştür.

Annelerin bakım verdiği süre, çocuğun tanı süresi ve hastaneye tekrarlı yatışların artması ile bakım yükünün arttığı tespit edildi. Benzer şekilde diğer çalışmalarda da bakım verilen süre arttıkça bakım verenlerin yükünün arttığını göstermiştir $(1,2,14,19,27)$.

Kronik hastalığı olan çocukların annelerinde anksiyete risk puan ortalaması $11,51 \pm 4,07$, depresyon risk puan ortalaması 9,96 $\pm 4,03$ olduğu belirlendi. Yılmaz ve ark.'nın (2008) çalışmasında astımlı ve kistik fibrozisli çocukların annelerinde anksiyete risk puan ortalaması $8,4 \pm 4,3,8,0 \pm 4,2$, depresyon risk puan ortalaması $6,5 \pm 3,9,6,5 \pm 3,8$ olduğu bildirilmiştir. Bir diğer çalışmada astımlı çocukların annelerinde anksiyete risk puan ortalaması $8,5 \pm 4,1$, depresyon risk puan ortalaması $6,7 \pm 4,1$ olduğu belirtilmiştir (11).

Araştırmada köy/kasabada yaşayan annelerin anksiyete, depresyon puan ortalamaları ilçede yaşayan annelere göre daha yüksek bulundu. Sevinç ve ark.'nın (2010) çalışmasında da astımlı çocukların annelerinde ikamet edilen yer ile anksiyete-depresyon düzeyi arasında ilişki olduğu bildirilmiştir (18). Bu sonuç yaşanılan yer ile hastaneye ulaşımın zorlaşması, yaşanılan yerde yeterli sağlık hizmeti alacak imkanların olmaması aileler üzerinde ek bir strese neden olabileceğinden kaynaklı olduğu düşünülmektedir.

Ailenin ekonomik durumunun kötü olması ile anksiyetedepresyon puanı arasında anlamlı bir ilişki tespit edildi. Sevinç ve ark.'nın (2010) çalışmasında astımlı çocukların annelerinin anksiyete ve depresyon puan ortalamalarının ekonomik durumdan etkilendiği ifade edilmiştir (18). Aile içerisinde kronik hastalığa sahip bireyin olması ailenin ekonomik giderlerini artırmaktadır (1). Ekonomik durumun kötü olması aile içerisinde stres nedeni olması yanında kronik hastalığı olan çocuğun olması ailenin ekonomik yükünü artırması nedeniyle elde edilen bulgular öngörülebilmektedir. Hemşirelere ekonomik durumu kötü olan ebeveynlerde anksiyete-depresyon gelişebileceğini göz önünde bulundurmalıdır ve bakım planında bu yönden değerlendirme yapmalıdır.

Annelerin çocuk sayısının artmasıyla depresyon puan ortalamasının arttığı belirlendi. Bir diğer çalışmada da çocuk sayısı ile anksiyete-depresyon düzeyi arasında ilişki olduğu belirtilmiştir (29). Annelerin bakmakla yükümlü olduğu başka çocuklarının olması, kronik hastalığı olan çocuklarıyla ilgilenme sırasında diğer çocuklarının bakımını yürütecek kişilere intiyaç doğurmasından kaynaklı olabilir.

Çocuklarına bakım verme sürecinde diğer çocuklarına bakım rolleri etkilenen annelerin anksiyete-depresyon puan ortalamalarının arttığı saptandı. Benzer şekilde bir çalışmada bakım rolleri etkilenen annelerin günlük yaşamlarının etkilendiği belirtilmiştir (8). Kronik hastalık süreci hastaneye tekrarlı yatışlar ve sık kontroller içermesi annenin iş ve aile ortamındaki rollerinde farklılıklara ve kişilerde anksiyete, depresyon, ağrı, stres, uykusuzluk, yorgunluk gibi sorunlara neden olmaktadır (19).

Çocuğunun hastalığı hakkında eğitim alan annelerin anksiyete, depresyon puan ortalamalarının daha yüksek olduğu bulundu. Bu sonucun annelerin hastalık ve hastalık süreci hakkında bilgi sahibi olması gelecek hakkında kaygı, umutsuzluk yaşamalarından kaynaklı olabileceği düşünüldü. Ancak bilgilendirme sürecinin ve içeriğinin incelenmesi gerektiği düşünüldü.

Çocukların yaşları büyüdükçe annelerin depresyon puanlarının arttığı, yedi yaş ve üzeri olan çocukların annelerinde depresyon puan ortalaması $0-1$ yaş grubundaki çocukların annelerinden daha fazla olduğu belirlendi. Fiziksel engelli çocuklara bakım veren kişilerde bakım 
yükünün, bakım verilen kişinin yaşının artmasıyla arttığı belirtilmiştir (23). Kronik hastalık süreci aileleri sosyal, psikolojik ve fizyolojik olarak etkilemektedir $(11,19,30)$. Bu etkilenmenin artması bakım verilen sürenin artmasına da yol açmaktadır.

\section{Sonuç ve Öneriler}

Kronik hastalığı olan çocukların annelerinin bakım yükleri artmakta ve anskiyete depresyon risk düzeyleri etkilenmektedir. Annelerin bakım yükü, anksiyete ve depresyon risk düzeylerini yaşanılan yer, ailenin aylık gelir düzeyi, bakıma yardımcı kişi veya kişilerin varlığı, bakım verme süresindeki rollerinin etkilenmesi, çocuğun hastalığı hakkında eğitim alma, bakım verilen çocuğun yaşı, bakım verilen sürenin uzaması ve tekrarlı yatışların olması olumsuz etkilenmektedir. Annelerin bakım yükünün artması ile anksiyete depresyon düzeyleri artmaktadır. Anne, aile

\section{Kaynaklar}

1. Törüner EK, Büyükgönenç L. Çocuk Sağlığı Temel Hemşirelik Yaklaşımları. Ankara: Göktuğ Yayıncılık; 2017. ss.185-205.

2. Ağkaya Alahan N, Aylaz R, Yetiş G. Kronik Hastalığı Olan Çocuğa Sahip Ebeveynlerin Bakım Verme Yükü. İnönü Üniversitesi Sağlık Bilimleri Dergisi 2015;4:1-5. http://193.140.142.206:8080/xmlui/bitstream/ handle/11616/4981/makale.pdf?sequence $=1$ \&isAllowed $=y$

3. Doğru SSY, Arslan E. Engelli Çocuğu Olan Annelerin Sürekli Kaygı Düzeyi ile Durumluk Kaygı Düzeylerinin Karşılaştırılması. Selçuk Üniversitesi Sosyal Bilimler Enstitüsü Dergisi 2008;1:543-53. https:// www.researchgate.net/publication/26517227_ENGELLI_COCUGU_ OLAN_ANNELERIN_SUREKLI_KAYGI_DUZEYI_ILE_DURUMLUK_KAYGI_DUZEYLERININ_KARSILASTIRILMASI

4. Kardaş Özdemir F, Akgün Şahin Z, Küçük D. Kanserli Çocuğu Olan Annelerin Bakım Verme Yüklerinin Belirlenmesi. Yeni Tıp Derg 2009;26:153-8. https://docplayer.biz.tr/4797344-Kanserli-cocuguolan-annelerin-bakim-verme-yuklerinin-belirlenmesi.html

5. Er M. Çocuk, Hastalık, Anne-Babalar ve Kardeşler. Çocuk Sağlığı ve Hastalıkları Derg 2006;49:155-68. http://www.cshd.org.tr/uploads/ pdf_CSH_206.pdf

6. Karakavak G, Çırak Y. Kronik Hastalıklı Çocuğu Olan Annelerin Yaşadığı Duygular. Eğitim Fakültesi Dergisi 2006;7:95-112. http:// www.manevisosyalhizmet.com/wp-content/uploads/2010/03/ kronik_hastalikli_cocugu_olan_annelerin_yasadigi_duygular.pdf

7. Çevik Ü, Keleş S, Keser M, Reisli İ. Astımlı Çocuğu Olan Ebeveynlere Verilen Hemşirelik Eğitiminin Kaygı Düzeylerine Etkisi. Genel Tıp Derg 2006;16:53-9. http://geneltip.org/upload/sayi/48/GTD-00354.pdf

8. Çakan P, Sezer Ö. Süreğen Hastalığı Olan Çocuklara Sahip Annelerin Tutumları, Kaygı Düzeyleri ve Diğer Değişkenler Açısından İncelenmesi. Fırat Üniversitesi Sosyal Bilimler Derg 2010;20:161-80.

9. Özkaya E, Çetin M, Uğurad Z, Samancı N. Evaluation of Family Functioning and Anxiety-Depression Parameters in Mothers of Children With Asthma. Allergol Immunopathol (Madr) 2010;38:2530. [CrossRef]

10. Mollaoğlu M, Özkan Tuncay F, Kars Fertelli T. İnmeli Hasta Bakım Vericilerinde Bakım Yükü ve Etkileyen Faktörler. Dokuz Eylül Üniversitesi Hemşirelik Yüksekokulu Elektronik Derg 2011;4:125-30. http://acikerisim.deu.edu.tr:8080/xmlui/ bitstream/handle/20.500.12397/4595/125-130_mollaoglu. pdf? sequence $=1$ \&isAllowed $=y$ içerisinde birçok görev, rol ve sorumluluğu olan bireydir ve çocuğunun hasta olması, hastalık süreci anneleri sosyal, fiziksel ve psikolojik olarak etkilemektedir. Annelerin yaşadığı bu olumsuzlukların önlemesin de hemşirelerin önemli bir rolü olabilir. Bu araştırma sonuçlarına göre hemşireler bakım verme yükü, anksiyete ve depresyon yönünden annelerin değerlendirilmesi ve bakım planını yaparken dikkate alması yararlı olacaktır. Hemşireler annelere bakım konusunda desteklemesi/teşvik etmesi, bakıma katması ve işbirliği yapması yani aile merkezli bakım çerçevesinde görevlerini yerine getirmesi önerilmektedir. Annelerin destek kaynaklarının düzenli değerlendirilmesi, incelenmesi, geliştirilmesi yaşanan olumsuz duyguların azaltılmasında rol oynayabilir. Annelere klinik içerisinde ve sonrasında danışmanlık hizmeti ve eğitim verilmesi, ulusal olarak annelerin yardım alabileceği kurum ve kuruluşların yaygınlaştırılması ve geliştirilmesi önerilmektedir.

11. Yüksel H, Sögüt A, Yilmaz O, Demet M, Ergin D, Kirmaz C. Evaluation of Sleep Quality and Anxiety-Depression Parameters in Asthmatic Children and Their Mothers. Respir Med 2007;101:2550-4. [CrossRef]

12. Yılmaz Ö, Söğüt A, Gülle A, Can D, Ertan P, Yüksel H. Sleepy Quality and Depression-Anxiety in Mother of Children with Two Chronic Respiratory Disease: Asthma and Cystic Fibrozis. J Cyst Fibros 2008;7:495-500. [CrossRef]

13. Özyazıcıoğlu N, Güdücü Tüfekci F. Yenidoğan Yoğun Bakım Ünitesinde Bebekleri Bakım Alan Annelerin Kaygı ve Umutsuzluk Düzeylerini Etkileyen Faktörlerin İncelenmesi. Atatürk Üniversitesi Hemşirelik Yüksekokulu Derg 2009;12:66-73. http://static.dergipark. org.tr/article-download/imported/1025000757/1025000742.pdf?

14. Atagün Mi, Devrim Balaban Ö, Atagün Z, Elagöz M, Özpolat AY. Kronik Hastalıklarda Bakım Verenin Yükü. Psikiyatride Güncel Yaklaşımlar 2011;3:513-52. [CrossRef]

15. Yeşil T, Çetinkaya Uslusoy E, Korkmaz M. Kronik Hastalığı Olanlara Bakım Verenlerin Bakım Yükü ve Yaşam Kalitesinin incelenmesi. Gümüşhane Üniversitesi Sağlık BilimleriDerg 2016;5:54-66. http://static.dergipark.org.tr/article-download/ fdc2/7e9f/53ab/5a1c5f99cae61.pdf?

16. Türk Dil Kurumu. http://tdk.gov.tr/index.php?option=com gts\&arama $=$ gts\&guid=TDK.GTS.5692972855C9f5.70737525

17. Tel H, Demirkol D, Kara S, Aydın D. KOAH'ı Hastaların Bakım Vericilerinde Bakım Yükü ve Yaşam Kalitesi. Türk Toraks Derg 2012;13:87-92.

18. Sevinç Ş, Pirinççioğlu AG, Kelekçi S, Şen V, Gürkan F. Astımlı Çocukların ve Annelerinin Depresyon ve Kaygı Düzeylerinin Değerlendirilmesi. Mustafa Kemal Üniversitesi Tıp Fakültesi Derg 2010;2:21-8. [CrossRef]

19. Çavuşoğlu H. Çocuk Sağlığı Hemşireliği, 12. Baskı. Ankara: Sistem Ofset Basımevi; 2015. ss.1-50.

20. Sümbüloğlu K, Sümbüloğlu V. Biyoistatistik 12. Baskı. Ankara: Hatiboğlu Yayınevi; 2007. ss.255-6.

21. Inci $F H$, Erdem M. Bakım Verme Yükü Ölçeği'nin Türkçe'ye uyarlanması Geçerlilik ve Güvenirliği. Atatürk Üniversitesi Hemşirelik Yüksekokulu Derg 2008;11:85-95. http://static.dergipark.org.tr/ article-download/imported/1025000688/1025000680.pdf?

22. Aydemir Ö. Hastane Anksiyete ve Depresyon Ölçeği Türkçe Formunun Geçerlilik ve Güvenilirlik Çalışması. Türk Psikiyatri Derg 1997;8:280-7. 
23. Karahan AY, İslam S. Fiziksel Engelli Çocuk ve Yaşlı Hastalara Bakım Verme Yükü Üzerine Bir Karşılaştırma Çalışması. Marmara Üniversitesi Sağlık Bilimleri Enstitüsü Derg 2013;13:51-7. [CrossRef]

24. Uludağ A, Güdücü Tüfekci F. Konjenital Kalp Hastalığı Olan Çocukların Ebeveynlerinde Bakım Yükü ve Yaşam Doyumu ile Algıladıkları Sosyal Destek Arasındaki İlişki. Atatürk Üniversitesi Sağlık Bilimleri Fakültesi Çocuk Sağlığı ve Hastalıkları Hemşireliği Anabilim Dalı, Yüksek Lisans Tezi, 2014, Erzurum, Türkiye.

25. Javalkar K, Rak E, Philips A, Haberman C, Ferris M, Van Tilburg M. Predictors of Caregiver Burden among Mothers of Children with Chronic Conditions. Children (Basel) 2017;4:2-10. [CrossRef]

26. Mashayekhi F, Jozdani RH, Chamak MN, Mehni, S. Caregiver Burden and Social Support in Mothers with $\beta$-Thalassemia Children. Global J Health Sci 2016;8:206-12. [CrossRef]

27. Yıldız E, Karakaş SA, Güngörmüş Z, Cengiz M. Levels of Care Burden and Self-efficacy for Informal Caregiver of Patients with Cancer. Holist Nurs Pract 2017;31:7-15. [CrossRef]
28. Özkan Tuncay F, Mollaoğlu M, Kars Fertelli T. Kronik Hastalığı olan Bireye Bakım Verenlerde Bakım Yükü ve Sosyal Destek Düzeyi. www.literatursempozyum.com 2015;8:5-10. http://www. literatursempozyum.com/pdf/m_1453712649.pdf

29. Safa M, Khalilzadeh S, Firoozeh T, Alizadeh S. Coorelation of AnxietyDepression and Sleep Quality in Mothers of Children with Cystic Fibrozis and Asthma. Tanaffos 2012;11:44-8. https://www.ncbi.nlm. nih.gov/pmc/articles/PMC4153183/

30. Toros F, Tot \$̧, Düzovalı Ö. Kronik Hastalığı Olan Çocuklar, Anne ve Babalarındaki Depresyon ve Anksiyete Düzeyleri.J Clin Psy 2002;5:240-7. https://www.journalagent.com/kpd/pdfs/ KPD_5_4_240_247.pdf 